\section{A CHECKLIST OF SOME LEAFY VEGETABLES USED BY TRIBALS IN AND AROUND RANCHI, JHARKHAND}

\author{
Bandana Kumari ${ }^{1}$ and Sudhanshu Kumar ${ }^{2}$ \\ ${ }^{1}$ P.P.K. College, Bundu, Ranchi, Jharkhand, India. \\ ${ }^{2}$ E 4/1 Urmila Ray Complex, Circular Road, Ranchi, Jharkhand \\ 834001, India.
}

Ranchi $\left(23^{\circ} 20^{\prime} \mathrm{N}\right.$ and $\left.85^{\circ} 20^{\prime} \mathrm{E}\right)$, the largest city of Chotanagpur is inhabited by a number of tribes from time immemorial (Gupta, 1974). Although a fast growing cosmopolitan city, it has preserved the culture of its original inhabitants. The tribes, primarily food-gatherers, have learned by experience to depend heavily on locally available vegetables for their nutritional and medicinal needs.
Food is the one absolute need for humans and the history of man perhaps could be written in terms of diet. Nutrition as a biological process is fundamental for self preservation and the preservation of species. Food habits of men developed on the basis of experience and survival through successive generations (Richards, 1948).

Tribal traditional food supply is mainly based on collection, hunting, and crop cultivation. Local vegetables make one of the most important food item of the tribal people of Chotanagpur Plateau along with agriculture products like rice, cereals and millets (Gupta, 1974).

Tribal concept of health varies greatly. However, they have learned to use vegetables as a cure to and prevention of many diseases. Regarding the origin of such a tradition, practically nothing is known. Probably it developed by experience (Gupta, 1965).

Vegetables used by tribal people and sold in markets in and around Ranchi are reported here. They are still not commonly used by nontribals.

The authors have collected the leafy vegetables being sold in

Table 1. Leafy vegetables (Sag) used by tribal communities in and around Ranchi, Jharkhand

\begin{tabular}{|c|c|c|c|c|c|c|c|}
\hline Botanical Name & $\begin{array}{l}\text { Names in lo } \\
\text { Common } \\
\text { Name }\end{array}$ & $\begin{array}{l}\text { cal languages } \\
\text { Santhal }\end{array}$ & Oraon & Mundari & Habit* & Habitat** & Medicinal use \\
\hline \multicolumn{8}{|l|}{ Amaranthaceae } \\
\hline 1. Amaranthus spinosus Linn. & Katabhaji & \multicolumn{3}{|c|}{ Kanteli Chawli Achcharaxa Achparara } & $\mathrm{H}$ & WP & Blood Purifier, Colic,Piles. \\
\hline 2. Achyranthus aspera Linn. & Chirchiri & Chirchithi & Chirchithi & Chirchithi & $\mathrm{H}$ & WP & $\begin{array}{l}\text { Cough, cold, Colic, Dropsy, Eye complains, } \\
\text { Laxative, Piles. }\end{array}$ \\
\hline 3. Alternanthera sessilis Linn. & Sarauchi & Gundri & Gandur & Gerunundi & $\mathrm{H}$ & WL & Fracture, Eye complaints, Malaria \\
\hline 4. A. philoxeroides (Mar.) Griseb. & Hencha & - & - & - & $\mathrm{H}$ & WL & Urinary complains \\
\hline 5. Celosia argentea Linn. & Safedmurg & Siliari & Kim Araxa & Sirgiti Ara & $\mathrm{H}$ & WF & Blood purifier, Dysentery \\
\hline $\begin{array}{l}\text { Apiaceae } \\
\text { 6. Centella asiatica (Linn.) Urban }\end{array}$ & Brahmi & Bengsag & Muxaarxa & Chokeara & $\mathrm{H}$ & $\begin{array}{l}\text { WL } \\
\text { complaints. }\end{array}$ & Blood dysentry, Cooling, Leprosy, Eye \\
\hline Begoniaceae & & & & & & & \\
\hline 7. Begonia picta Sm. & - & \multicolumn{3}{|c|}{ Pakhanachatta Pakhanchatta Lundiara } & $\mathrm{H}$ & WL & Colic, Dysentery, Ulcer in mouth \\
\hline 8. Cordia dichotoma Forst.f. & Losora & Buch & Dhanul & Bunch & $\mathrm{T}$ & $\mathrm{F}$ & Colic, Cough, Dysentery, Jaundice, Ulcer. \\
\hline $\begin{array}{l}\text { Caesalpinaceae } \\
\text { 9. Bauhinia purpurea Linn. }\end{array}$ & Koinar & Singarak & Komaarxa & Singara & $\mathrm{T}$ & $\mathrm{F}, \mathrm{CL}$ & Swelling, Pain. \\
\hline 10. B. retusa Roxb. & Kanla & Teor & Teor & Laba & $\mathrm{T}$ & $\mathrm{F}$ & Sores \\
\hline 11. Cassia occidentalis Linn. & Kasondi sag & $\begin{array}{l}\text { Barka } \\
\text { chakonda }\end{array}$ & $\begin{array}{l}\text { Koha } \\
\text { chakonda }\end{array}$ & $\begin{array}{l}\text { Murang } \\
\text { chakonda }\end{array}$ & $\mathrm{H}$ & WP & Gastric, Dropsy, Cough, Piles. \\
\hline 12. C. tora Linn. & Chakor & Chakonda & $\begin{array}{l}\text { Sunny } \\
\text { chakonda }\end{array}$ & $\begin{array}{l}\text { Huring } \\
\text { chakon }\end{array}$ & $\mathrm{H}$ & WP & Intestinal disorder, Jaundice, Night blindness. \\
\hline
\end{tabular}




\begin{tabular}{|c|c|c|c|c|c|c|c|}
\hline \multirow[t]{2}{*}{ Botanical Name } & \multicolumn{4}{|c|}{ Names in local languages } & \multirow[t]{2}{*}{ Habit* } & \multirow[t]{2}{*}{ Habitat** } & \multirow[t]{2}{*}{ Medicinal use } \\
\hline & $\begin{array}{l}\text { Common } \\
\text { Name }\end{array}$ & Santhal & Oraon & Mundari & & & \\
\hline \multicolumn{8}{|l|}{ Capparidaceae } \\
\hline 13. Cleome monophylla Linn. & Hurhuria & Hurhuria sag & Tota sirio & \multicolumn{2}{|c|}{ Charmani ara $\mathrm{H}$} & WP & Potherb against bile \\
\hline 14. C. gynandra Linn. & Hul hul & Sada hurhuria & & \multicolumn{2}{|c|}{ Pundi charmani $\mathrm{H}$} & WP & Ear complaints, Stiff neck \\
\hline 15. C. viscosa Linn. & Kan phutti & Hurhuria & Nal sirio & \multicolumn{2}{|c|}{ Marang charmani $\mathrm{H}$} & WP & Boils Ear ache \\
\hline \multicolumn{8}{|l|}{ Commelinaceae. } \\
\hline 16. Commelina benghalensis Linn. & Kenasag & Golgolau sag & Kena arxa & Undupu ara & $\mathrm{H}$ & WP & Laxative, Wounds \\
\hline \multicolumn{8}{|l|}{ Convolvulaceae. } \\
\hline $\begin{array}{l}\text { Euphorbiaceae } \\
\text { 18. Antidesma diandrum Roxb. }\end{array}$ & Amti sag & Matha Arak & Kundui & Mata Ara & $\mathrm{S}$ & ST & $\begin{array}{l}\text { Bilious complaints, Blood dysentery, } \\
\text { Muscular pain. }\end{array}$ \\
\hline 19. Euphorbia hirta Linn. & Dudhisag & Dudhia & Dudhia & Marang dudh & & WP, WF & Asthma, Cough, Joint Pain, Dysentery. \\
\hline \multicolumn{8}{|l|}{ Moraceae } \\
\hline 20. Ficus geniculata Kurz & Putkal & Putkal & Putkal & Jait Putkal & $\mathrm{T}$ & $\mathrm{F}$ & Colic, Dysentery \\
\hline 21. F. infectoria Roxb. & Pakar & Phutkal & Phutkal & Hesa Putkal & $\mathrm{T}$ & $\mathrm{F}$ & Colic, Dysentery. \\
\hline \multicolumn{8}{|l|}{ Nyctaginaceae } \\
\hline 22. Boerhaavia diffusa Linn. & Punarnava & Khapra Sag & Khapra Arxa & Kecho Ara & C & WP & $\begin{array}{l}\text { Eye diseases, Dropsy, Oedema, Jaundice, } \\
\text { Low blood pressure }\end{array}$ \\
\hline \multicolumn{8}{|l|}{ Oxalidaceae } \\
\hline 23. Oxalis corniculata Linn. & Khatmithisag & Amboti & Kisspunji & Pirijojo & $\mathrm{H}$ & WP & $\begin{array}{l}\text { Appetizer, Cough, Eye complaints, jaundice, } \\
\text { Rickets, Scurvy, Piles. }\end{array}$ \\
\hline \multicolumn{8}{|l|}{ Polygonaceae } \\
\hline 24. Polygonum barbatum Linn. & Sake sag & Sake Sag & Sake arxa & Madara & $\mathrm{H}$ & WL & Piles \\
\hline 25. P. glabrum Willd. & Puror & - & - & Sukuripota & $\mathrm{H}$ & ST & Anthelmintic, Fever \\
\hline 26. P. plebeium R. Br. & Chimti Sag & Chimti Sag & Pok Arxa & Muiara & $\mathrm{H}$ & WP & $\begin{array}{l}\text { Cough, Dysentery, Lactation, Gastric } \\
\text { complaints. }\end{array}$ \\
\hline 27. Rumex vesicarius Linn. & Banpalak & Tissa Palak & Tissa palak a & arxa - & $\mathrm{H}$ & WP & Laxative \\
\hline \multicolumn{8}{|l|}{ Portulacaceae } \\
\hline 28. Portulaca oleracea Linn. & Golgola sag & Golgola sag & \multicolumn{2}{|c|}{ Addota txa arxa Dailara } & $\mathrm{H}$ & WP & $\begin{array}{l}\text { Blood purifier, Fever, Prickly heat and } \\
\text { Burning sensation }\end{array}$ \\
\hline 29. Portulaca quadrifida Linn. & Noni sag & Garujib sag & \multicolumn{3}{|c|}{ Addota txa arxa Golgol Ara H } & WP & Burns, Ulcers. \\
\hline $\begin{array}{l}\text { Rubiaceae } \\
\text { 30. Vangueria spinosa Roxb. }\end{array}$ & Sarla sag & Sarla Kanta & Sarla Achch & Serilia Ara & $\mathrm{S}$ & $\mathrm{F}$ & Dysentery \\
\hline Vitaceae & & & & & & & \\
\hline 31. Cissus adnata Roxb. & Khata sag & - & - & - & C & $\mathrm{F}$ & Blood purifier, Diuretic, Piles. \\
\hline Marsileaceae (Pteridophyte) & & & & & & & \\
\hline 32. Marselia minuta Linn. & Sunsunia sag & Sushni shak & - & Catam ara & $\mathrm{H}$ & WL & Pimples, Eye complaints, Fever. \\
\hline Ophioglossaceae & & & & & & & \\
\hline 33. Ophioglossum reticulatum Linn. & Sugga sag & Jibhia & - & - & $\mathrm{H}$ & WL & Boils, Hair tonic. \\
\hline
\end{tabular}

* Type of Plant: H - Herb, S - Shrub, T - Tree, C - Creeper.

** Habitat: WP - Waste Places, CL - Cultivated, WF - Weed in Agricultural Field, DL - Dry Land, WL - Wet Land, ST - Near streams, F - Forest. 
markets in and around Ranchi for two years. The vegetables have been identified with the help of the flora by Haines (192125) and for up-to-date nomenclature Ghosh (1971) has been consulted. For their nutraceutical properties and medicinal values Jain (1991) has been consulted.

\section{References}

Ghosh, T.K. (1971). Studies on flora of Ranchi District. Ph.D. Thesis. 1-2 vols. University of Ranchi.

Gupta, S.P. (1965). An apprasial of Chotanagpur tribal pharmacoepia. Bulletin of the Bihar Tribal Research Institute 5(2), 263-280.

Gupta, S.P. (1974). Tribes of Chotanagpur Plateau: An Ethno-nutrition and Pharmacological Cross-section. Bihar Tribal Welfare Research Institute, Ranchi.

Haines, H.H. (1921-25). The Botany of Bihar and Orissa. Vol. 1-4. Jain, S.K. (1991). Dictionary of Indian Folk Medicine and Ethnobotany. Deep Publications, New Delhi.

Richards. A.I. (1948). Hunger and Work in a Savage Tribe. The Free Press, Glencoe, Illinois.

\section{ETHNOBOTANY OF WILD SALAD (RAIMODI) IN GARHWAL HIMALAYA}

\section{V.P. Bhatt}

Scientist, Herbal Research and Development Institute, Gopeshwar, Chamoli Garhwal, Uttaranchal 246401, India.

Most temperate valleys in the high altitudes of Garhwal Himalaya are inhabited by ethnic communities. Khasas and Doms are two such communities who are traditionally rich in various social, cultural and religious rituals that are performed throughout the year. However, due to many anthropocentric developmental ideas, many of these wise social sustainable practices have been lost and a surviving few cultural resources are on the verge of extinction. The tradition of making wild salad (Raimodi) by the Himalayan women in the forest is one of the few surviving traditionally-rich cultural skills. The plants used in making raimodi are petals of Rhododendron arboreum, Smith (En. Tree-

Received on 7 February 2000

Accepted on 10 October 2000
Rhododendron, E. Buransa-phool), leaves and flowers of Rumex hastatus, D. Don. (E. Almodo, U. Amlodo, G. Chalmodo), leaves of Raphanus sativus, L. (En. Radish, E. Mooli), Brassica juncea, Hook.f. et T. (En. Indian mustard, E. Rai), Coriandrum sativum, L. (En. Coriander, E. Dhandya-patta), Spinacia oleracea, L. (En. Spinach, E. Palinga-patta), Trigonella foenum-graecum, L. (En. Fenugreek, E. Methi) and tender branches of Lathyrus sativus, L. (En. Grasspea, E. Tukhla).

In the early spring season, the wives of grass-cutters mix all the items of this nutrition-rich diet with special salt (Peesyon-lwond) on a stone (Raimodi-dhungo) especially fixed in the forest to prepare this native Himalayan dish. However, in district Uttarakashi only the petals of Rhododendron and Rumex nepalensis, Speng. (U. Amlodo) are separately eaten with salt. A folk song inviting the persons to enjoy this delicious wild salad is sung throughout the parts of the Garhwal Himalaya.

'Awa dagadyo, awa bhai bando

Tai jungle joola, raimodi meelai kholla'

It is said that some decades ago, the village daughters-in-law were given very less nutritious diet and even sometimes were not allowed to take complete diet. In those circumstances knowledge of making raimodi was adopted by these intelligent women to fulfil their nutritional requirement. But now, since most families depend on ration supplied from the market, the traditional use of valuable and common wild plant resources has been decreasing at the rate faster than ever. The spread of diseases like breast and ovarian cancer, pernicious anaemia, blood pressure, diabetes, heart diseases in remote areas are some of the direct and discernible effects of adopting modern food habits.

Lack of public awareness about the benefits of using wild herbs is also a cause for concern. Now the Himalaya needs conservation of itself along with the restoration of dwindling cultural, social and traditional sustainable practices gained by the ethnic and tribal communities through generations.

Abbreviations used: E. - Ethnic; En.- English; G. - Gairsain block in Chamoli District; U. - Uttarakashi District. 